\title{
REGIONAL ARCHAEOLOGY AND LOCAL INTERESTS IN COIXTLAHUACA, OAXACA
}

\author{
Stephen A. Kowalewski, Stefan P. Brannan, Marisol Yadira Cortés Vilchis, Laura Diego Luna, \\ Gabriela García Ayala, José Leonardo López Zárate, Fernando Méndez Sobel, \\ Laura R. Stiver Walsh, Ellen B. Turck, John A. Turck, and Sergei Vepretskiy
}

\begin{abstract}
The Recorrido Arqueológico de Coixtlahuaca (RAC) presents period-by-period settlement pattern maps for the valley of Coixtlahuaca in the northern Mixteca Alta. The RAC project made improvements in full-coverage survey methods. We identify limitations and suggest that similar projects in the future need to resolve several management and budget problems. The survey revealed two periods of heavy occupation, 700-300 BC and AD 1200-1520, separated by a long period of lower population. Archaeological and historical data indicate that during the AD 1200-1520 period, and probably earlier, small landholders organized in strong communities managed an intensive agroecosystem, investing in landesque capital. Urbanization was impressive, yet cities were aggregations of communities and barrios. Today local citizens pose questions about how the large prehispanic population could have organized and sustained itself; these questions coincide with anthropological interest in collective agency, property, landesque capital, and collapse.
\end{abstract}

En este artículo se presentan los mapas del patrón de asentamiento por período del valle de Coixtlahuaca, en el norte de la región de la Mixteca Alta, en el estado de Oaxaca, México. Estos datos fueron generados por el proyecto Recorrido Arqueológico de Coixtlahuaca (RAC). En el proyecto RAC se realizaron avances sobre los métodos de prospección de cobertura total. En este artículo se identifican ciertas limitaciones y se sugiere que proyectos similares a realizarse en el futuro deberán prever y resolver diversos problemas de presupuesto y gestión. Como resultado de la prospección se reconocieron dos periodos de intensa ocupación, 700-300 a.C. y 1200-1520 d.C., separados por un largo periodo de menor densidad poblacional. Los datos arqueológicos e históricos indican que durante el periodo de 1200 a 1520 d.C., y quizás antes, los pequeños productores agrícolas lograron el manejo de un agroecosistema intensivo, invirtiendo en capital en tierras ("landesque capital") y organizándose en fuertes comunidades locales. Aunque la urbanización fue impresionante, estas ciudades eran agregados de comunidades y barrios. Las preguntas planteadas por los ciudadanos locales modernos acerca de cómo la numerosa población prehispánica pudo mantenerse y organizarse son relevantes para los temas antropológicos de agencia colectiva, propiedad, capital en la forma de enmiendas a la tierra y colapso.

Stephen A. Kowalewski and Stefan P. Brannan — Department of Anthropology, University of Georgia, Athens, GA 30602, USA (skowalew@uga.edu, corresponding author; sbrannan@uga.edu)

Marisol Yadira Cortés Vilchis — Dirección de Salvamento Arqueológico INAH, Cordoba 45, Colonia Roma, Delegación Cuauhtémoc, 06700 Ciudad de México, México (coatlalpan@gmail.com)

Laura Diego Luna Estudios Mesoamericanos, Universidad Nacional Autónoma de México, Circuito de Posgrados, Edificio H, Cd. Universitaria, 04510 Ciudad de México, México (laudluna@gmail.com)

Gabriela García Ayala @ Centro de Investigación en Geografía Ambiental, UNAM-Morelia, Antigua Carretera a Pátzcuaro 8701, Colonia Ex Hacienda de San José de la Huerta, 58190 Morelia, Michoacán, Mexico (ggarcia@ pmip.unam.mx)

José Leonardo López Zárate - INAH Delegación Oaxaca, Pino Suárez 715, Centro Histórico, 68000 Oaxaca, Oaxaca, Mexico (cociyo2009@gmail.com)

Fernando Méndez Sobel $\square$ Colaborador Independiente, Oaxaca, Mexico (f-j-mendez@ hotmail.com)

Laura R. Stiver Walsh — Metro Nashville Public Schools, 2601 Bransford Avenue, Nashville, TN 37204, USA

(lrstiver@hotmail.com)

Ellen B. Turck — Upper Freehold Regional School District, 27 High Street, Allentown, NJ 08501, USA

(ellen.turck@gmail.com)

John A. Turck National Park Service, Valley Forge National Historical Park, 1400 North Outer Line Drive, King of Prussia, PA 19406, USA (john_turck@nps.gov)

Sergei Vepretskiy $\square$ State Academic University for the Humanities, Maronovsky St. 26, 119049 Moscow, Russia (ger44@mail.ru)

Latin American Antiquity 28(3), 2017, pp. 353-372

Copyright (C) 2017 by the Society for American Archaeology doi:10.1017/laq.2017.19 
$\mathrm{T}$ The Recorrido Arqueológico de Coixtlahuaca (RAC) systematically surveyed a key region in Mesoamerica. The settlement patterns that emerged shed light on problems in ecological and political anthropology. These problems were succinctly phrased in two questions that citizens of Coixtlahuaca posed to us at a public forum at the conclusion of our 2008 pilot project: How could such a large number of people have lived here in the past, when today, with a much lower population, we can barely make a living? And, how were all those people organized? The questions are important today because living on this spectacularly eroded land is difficult, and people are constantly confronted with the costs and benefits of social cooperation, withdrawal, or conflict. Local communities sometimes alternate between impressive collective action and paralyzing factionalism.

Our research was not based on the local citizens' questions-our goal from the start was to survey the region. But their questions coincide with more general anthropological concerns, and the problems are significant academically and practically. We made these questions the central theme of our successful proposal to the National Science Foundation for the regional survey. The population question involves agroecosystem processes that we are treating in detail, as are our colleagues the geomorphologists David Leigh and Genevieve Holdridge. In this article we focus on the question of social organization, although inevitably we refer to making a living as we address how people were organized.

¿Cómo se organizaron? ¿Cómo fueron organizados? Spanish and English share the ambiguity of the passive voice: How did they organize themselves? Or, how were they organized (by someone else)? A common perspective is that the elite organize society; they are the generative and most powerful force. The elite lead, establish cities, and populate them with their subjects. This is the perspective of the texts produced by Mesoamerican rulers. Nevertheless, recent studies using cooperation theory emphasize variation in degrees of autocratic or collective action (Blanton and Fargher 2008; Carballo 2013a). Coixtlahuaca settlement archaeology and historical sources show that community organization existed prior to king and state, and was powerful and enduring enough to contest both. Society was a complicated dynamic of opposed strategies.

\section{Study Area and Chronology}

The valley of Coixtlahuaca is the upper basin of the Río Xiquila, the northernmost valley of the Mixteca Alta (Figure 1). Valley floors in the Mixteca Alta are about 2,100 m asl and mountain crests rise to 2,800 m asl. The Mixteca Alta is in the geographical center of Mesoamerica and within it the Coixtlahuaca valley has the best access to the Gulf Coast lowlands. Soil and water management have been key factors in Mixteca Alta cultural ecology (Kirkby 1972; Spores 1969). Valleys have deep deposits of the Yanhuitlán and similar sedimentary formations. Soils derived from these are fertile but notoriously erodible, and these two characteristics have played a major part in the human history of this region. Climate is temperate and semiarid. Although each valley has permanent surface water, precipitation is erratic and, on average, marginal for rainfall agriculture, which places a premium on water control.

We selected this area because it was a large and powerful city-state in Late Postclassic times (e.g., Durán 1967:2:185-195). It had received little archaeological attention since Bernal's impressive study (Bernal 1948-1949; Spores 2007:50-51, 470). Surveying Coixtlahuaca would further expand the approximately $9,000 \mathrm{~km}^{2}$ area of archaeological coverage extending from central valleys of Oaxaca through much of the Mixteca Alta (Balkansky 2006).

In the past, the Coixtlahuaca valley was home to speakers of Chocholtec (Ngigua, Ngiwa; Huesca et al. 1984:2:3-18). Some towns also had speakers of Mixtec (van Doesburg 2001). Today only a few people speak an indigenous language. Many tell legends about the past, but the oral history has not been compiled and studied as fully as it should be (Grosser Lerner 2004; Jiménez García 2000; Rincón Mautner 1999). Coixtlahuaca has an important corpus of 13 native lienzos, which are graphic representations of geography and royal dynasty made in the sixteenth century. Below we juxtapose the archaeological and historical data, but more 


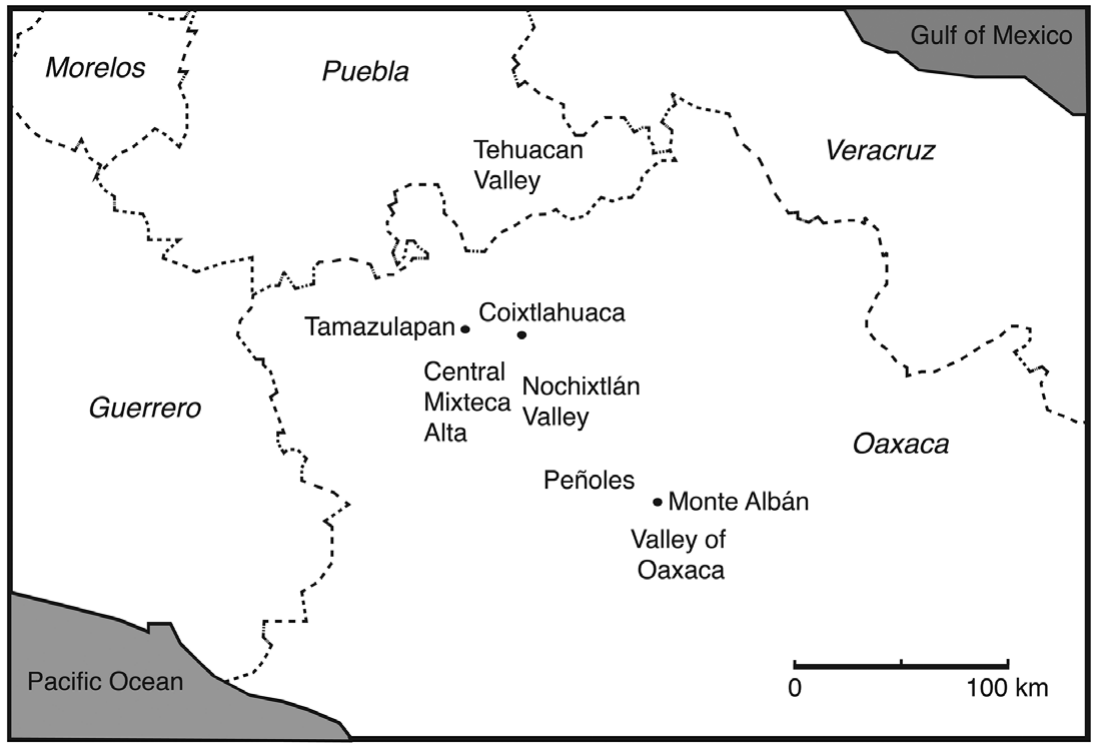

Figure 1. Location of Coixtlahuaca and surrounding places mentioned in the text.

detailed research should be done now that the archaeology is better known.

The ceramic chronology (Table 1) of Coixtlahuaca valley is similar to the adjacent Nochixtlán and Tamazulapan valleys (Blomster 2004; Byland 1980; Kowalewski et al. 2009; Plunket 1983; Spores 1972). Bernal carried out stratigraphic excavations at the Late Postclassic center in 1948-1949 and documented the ceramics. Our 2008-2011 work found evidence of Middle Formative through Early Classic occupation and pottery resembling ceramics from neighboring areas in the Mixteca Alta and the Valley of Oaxaca (Caso et al. 1967; Flannery and Marcus 1994). There are also links to Tehuacan, $60 \mathrm{~km}$ to the north (MacNeish et al. 1970).

\section{Field and Lab Methods}

The RAC survey began in 2008 at the ancient city of Coixtlahuaca. We used systematic surface survey, controlled collection, and multitechnique prospection, the latter carried out by our collaborators at the Laboratorio de Prospección, Instituto de Investigaciones Antropológicas, Universidad Nacional Autónoma de México (UNAM-IIA), under the direction of Luís A. Barba Pingarrón. We studied the history and internal makeup of the city, mapped its limits over time, improved our understanding of the chronology, and investigated residential density in 10 places. This work showed that Coixtlahuaca extended continuously, without gaps, over 3,000 ha.

In 2009, along with the UNAM-IIA team, we focused on three Late Postclassic residences and carried out test excavations to evaluate the remote sensing data. These studies provided a provisional estimate of residential density of four to seven houses per hectare for the Late Postclassic city (Kowalewski et al. 2011).

The 2011 project was the full-coverage survey of the whole valley; we have described the methods elsewhere (Kowalewski et al. 2009:1527). We were able to make important improvements in data management in this phase by using GIS more extensively to organize information, including GPS points and tracks, collections, photographs, notes, features, municipal boundaries, and other data. Each three- or fourperson field crew was responsible for data entry using a common template. In earlier regional projects, phase-by-phase settlement pattern maps were not completed until months after fieldwork, but in 2011 we drew component boundaries within a few days of a site being mapped, updating the field information as ceramic collections were initially classified and later reviewed. Early decision on component boundaries greatly 
Table 1. Chronology, Sites, and Total Site Area for the Valley of Coixtlahuaca.

\begin{tabular}{|c|c|c|c|c|}
\hline Years & Mesoamerica & Mixteca Alta & $\begin{array}{c}\text { Coixtlahuaca } \\
\text { Valley Sites }\end{array}$ & $\begin{array}{c}\text { Coixtlahuaca Valley Tota } \\
\text { Site Area (ha) }\end{array}$ \\
\hline \multicolumn{5}{|l|}{1500} \\
\hline 1400 & & & 401 & \\
\hline 1300 & Late Postclassic & Late Natividad & & 10215 \\
\hline \multicolumn{5}{|l|}{1200} \\
\hline 1100 & & & 19 & \\
\hline 1000 & Early Postclassic & Early Natividad & & $?$ \\
\hline \multicolumn{5}{|l|}{900} \\
\hline \multicolumn{5}{|l|}{800} \\
\hline 700 & Late Classic & Late Las Flores & & \\
\hline \multicolumn{5}{|l|}{600} \\
\hline 500 & & & 173 & \\
\hline 400 & Early Classic & Early Las Flores & & 2322 \\
\hline 300 & & (Transition) & & \\
\hline 200 & & & 5 & \\
\hline \multirow{2}{*}{ AD 100} & Late/Terminal & Late Ramos & & 209 \\
\hline & Formative & & 9 & \\
\hline BC 100 & & Early Ramos & & 147 \\
\hline \multicolumn{5}{|l|}{200} \\
\hline 300 & & & 245 & \\
\hline 400 & & Late Cruz & & 3023 \\
\hline 500 & Middle Formative & & & \\
\hline \multicolumn{5}{|l|}{600} \\
\hline 700 & & & 3 & \\
\hline 800 & & Middle Cruz & & 3 \\
\hline \multicolumn{5}{|l|}{900} \\
\hline \multicolumn{5}{|l|}{1000} \\
\hline 1100 & Early Formative & & & \\
\hline 1200 & & Early Cruz & & \\
\hline 1300 & & & & \\
\hline 1400 & & & & \\
\hline 1500 & & & & \\
\hline
\end{tabular}

improves data quality. Our experience suggests that regional surveys should make full use of databases and GIS, concurrent with fieldwork, for all information and research products. Artifacts were described and typed up within a few days of their collection and reviewed several times (by SAK and LRS). We photographed every artifact, front and back, by collection.

For each of 18 communities, we wrote individual reports describing the objectives, methods, results, significance, and need for preservation, and attached maps showing site locations. Field crews submitted the reports to communities in June 2011.

Regional surveys are always a tense balance between two competing objectives that cannot be maximized at the same time: covering as much area as possible and collecting more information on each site. It is too facile to conclude that the optimal solution depends on research objectives. In practice, research objectives do not anticipate every situation. The tension between extensive coverage and richer information does not disappear. Especially near the end of the field season, crews had too much to do and too little time. Later we found omissions and inconsistencies that we should have caught during earlier errorchecking. We had hoped to survey $1,000 \mathrm{~km}^{2}$, but completed about $660 \mathrm{~km}^{2}$ due to local political difficulties, because sites were more extensive than anticipated, and because of limitations on project resources and flexibility. The most significant gap in coverage is Tepelmeme, notable for the precolumbian paintings in the cave known as the Puente Colosal (Rincón Mautner 2005; Urcid 2004).

We collected 579 lots of artifacts at Coixtlahuaca in 2008. The 2011 regional survey 
collected 264 lots, and many hundreds of collections were inspected but not taken. Because smaller collections affect chronological discernment, more collections are desirable, and this requires standardized procedures for inspecting and collecting, which should be made clear in the research plan. Crews need to know about the ceramics at the outset.

Time spent on nonresearch issues is a concern. Project diplomacy has become more difficult and time-consuming in Oaxaca in the last several decades, with the weakening of federal and state government authorities and sometimes unpredictable local disputes and factions. In most instances the time spent in local diplomacy is rewarding, however. We learned a lot from community members and we appreciate having had the opportunity to work with them. Dealing with administrative obstacles imposed by one's university is also difficult and time-consuming, but in no sense rewarding. Many of the difficulties just cited should be anticipated at the proposal stage and dealt with in the budget. A project of this complexity requires more attention to management today than was once the case, and this should be addressed early in the planning stage.

\section{Settlement Patterns over Time}

\section{Paleoindian and Archaic (Prior to 2000 BC)}

We found no evidence of occupation in the Paleoindian period. Pleistocene megafaunal remains are often found in this part of Mexico, but thus far not in association with humans. Rock art (e.g., Ramírez 2014) and charcoal from a hearth dated to 3290-2920 cal BC (Rincón Mautner 1999:681-691, 694) are the only documented evidence for the Archaic.

\section{Early Formative (2000-700 BC)}

We have only three small habitation sites (Figure 2). These are on low hills overlooking the valley floor. In each case there are a few Middle Cruz sherds (ca. 1000 BC). One site was identified only after visiting colleague Marc Winter spotted a couple of sherds on a lab table. This site and another required revisits, and the third was quite disturbed, being in the middle of a present-day village. Early Formative sites are difficult to identify because diagnostics are sparse, there is heavy later occupation, and early occupations are more likely to be eroded away or buried by sediments.

Our geomorphological study suggests that more than a few farming households had settled here by 1500 BC. In a deeply incised stream bank near San Juan Bautista Coixtlahuaca, Leigh and Holdridge found a $6 \mathrm{~m}$ high cross-channel check dam. Ten radiocarbon samples date it to 3500-3400 cal BP (Leigh et al. 2013). A series of dams was built to control the force of the water during storms. This implies that there was cooperation among farmers, the number dependent on the size of the stream. Perhaps people had committed to sedentism by this early date, as MacNeish has proposed for Tehuacan, in "(linear) waterway hamlets" near moist barranca bottoms (MacNeish et al. 1972:155-160, 499500).

\section{Middle Formative (700-300 BC)}

The Middle Formative was a period of expansion (Figure 2). The number of settlements jumped to 245. Total settlement area exceeded 3,000 ha. One site alone extended continuously over 1,300 ha. Along the Río Grande de Ihuitlán, settlement covered large parts of the municipalities of Teopan, Jicotlán, Tepetlapa, and Ihuitlán. Tequixtepec and Naduza-Ñiaxugue in Coixtlahuaca (García Ayala 2011) were also major towns. These sites are extensive and offer dense scatters of pottery and chert debitage, with bellshaped pits, house foundations, and residential terraces.

Middle Formative ceramics resemble Rosario, Monte Albán Ia, and Monte Albán $\mathrm{Ib}$ in the Valley of Oaxaca (Caso et al. 1967; Drennan 1976) and Late Cruz (Spores 1972) and the Yucuita phase (Blomster 2004) in the Mixteca Alta. Our collections are not sufficient in size or number to map change in settlement size by shorter phases, since many diagnostics are relatively rare, but our impression is that settlement began in the early third of the Late Cruz period and was most extensive in the late third.

Most occupations are in open valley floors. There are also hilltop villages, some with 


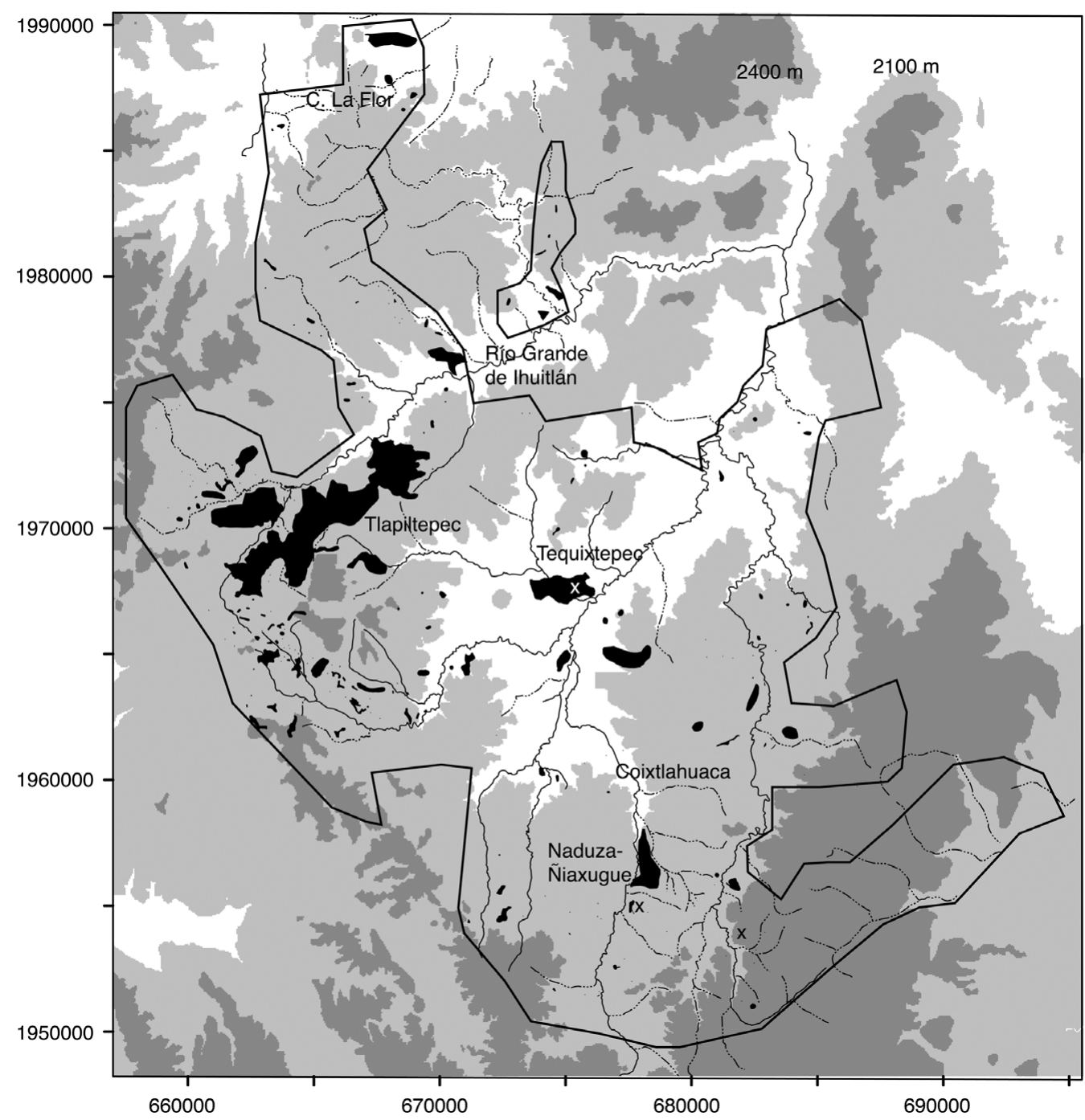

Figure 2. Late Cruz (700-300 BC) settlements in the valley of Coixtlahuaca. The black line shows the survey area. The edges of the gray shading indicate the $2,100 \mathrm{~m}$ and $24,00 \mathrm{~m}$ asl contours. The three known Middle Cruz sites are marked by $x$ 's.

rings of habitation terraces. The largest and best-preserved of the hilltop sites are NaduzaNiaxugue, Cerro La Flor at the northern edge of the region, and Tlapiltepec, where the center of the 1,300 ha settlement is an impressive hill town with rings of $6 \mathrm{~m}$ high terrace walls on the slopes and a small civic-ceremonial precinct on top of the hill.

The Coixtlahuaca valley has some of the most extensive Middle Formative sites recorded in Mesoamerica. The density of houses in these extensive artifact scatters is unknown. Visible house foundations are rare. If the density were 10 persons per hectare (the upper limit of "scattered village" and the lower limit of "compact low density" ranges [Sanders et al. 1979:3839]), the region could have had almost 30,000 people shortly before $300 \mathrm{BC}$. Radiocarbon and stratigraphic dating of check dams exposed in stream profiles indicate that agricultural terracing was extensive during this period.

There was not a lot of public architecture12 sites have a total of 22 small platform mounds that may date to this period. Platforms are widely 


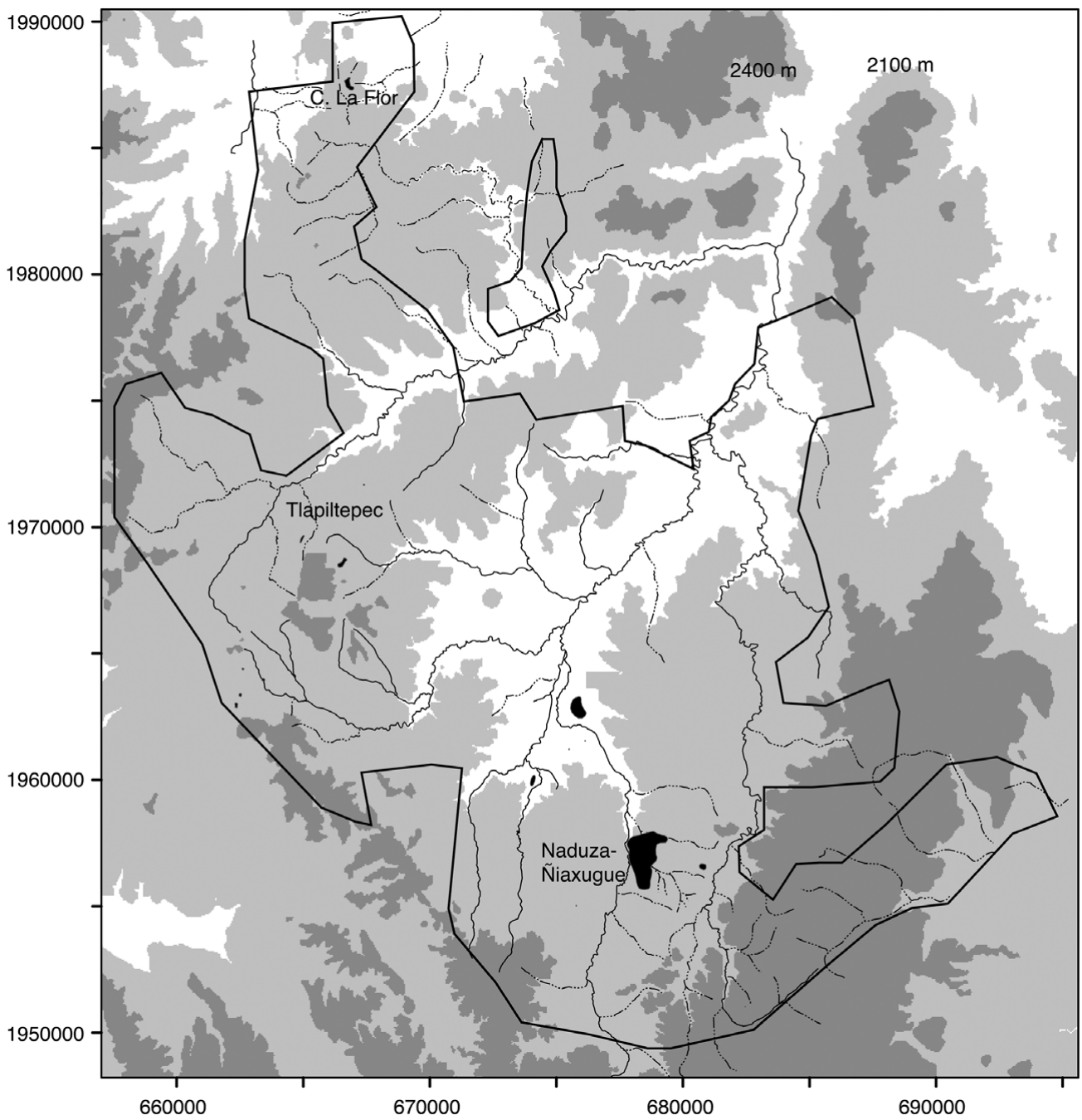

Figure 3. Ramos (300 BC-AD 200) settlements in the valley of Coixtlahuaca.

distributed. A few are at the centers of large settlements but most are at small sites or in boundary situations on hilltops at the edges of drainages.

\section{Late and Terminal Formative (300 BC-AD 200)}

This period (the Early and Late Ramos phases, coeval with Monte Albán Late I and II) saw a demographic trough (Figure 3 ). In the Late Formative, most of the valley was abandoned, except for the town of Naduza-Niaxugue (more than 100 ha); Cerro La Flor, a lingering small occupation at the formerly huge settlement at Tlapiltepec; and a few small sites that were probably not occupied for very long. In the
Terminal Formative, Naduza-Niaxugue persisted as a large town (over 180 ha), Cerro La Flor was abandoned, and there were just a few other small sites. Naduza-Niaxugue resembles its peer Yucuita, $20 \mathrm{~km}$ to the south in the Nochixtlán valley (Plunket 1983).

In sum, except for Naduza-Ñiaxugue, the Coixtlahuaca region was little occupied from about 300 BC to about AD 200. This decline was extreme, but it seems to coincide with the militarization and population stasis or decline seen in neighboring regions in the same period. It would be difficult to attribute the partial abandonment of Coixtlahuaca to deficiency in the ceramic chronology, since the same 


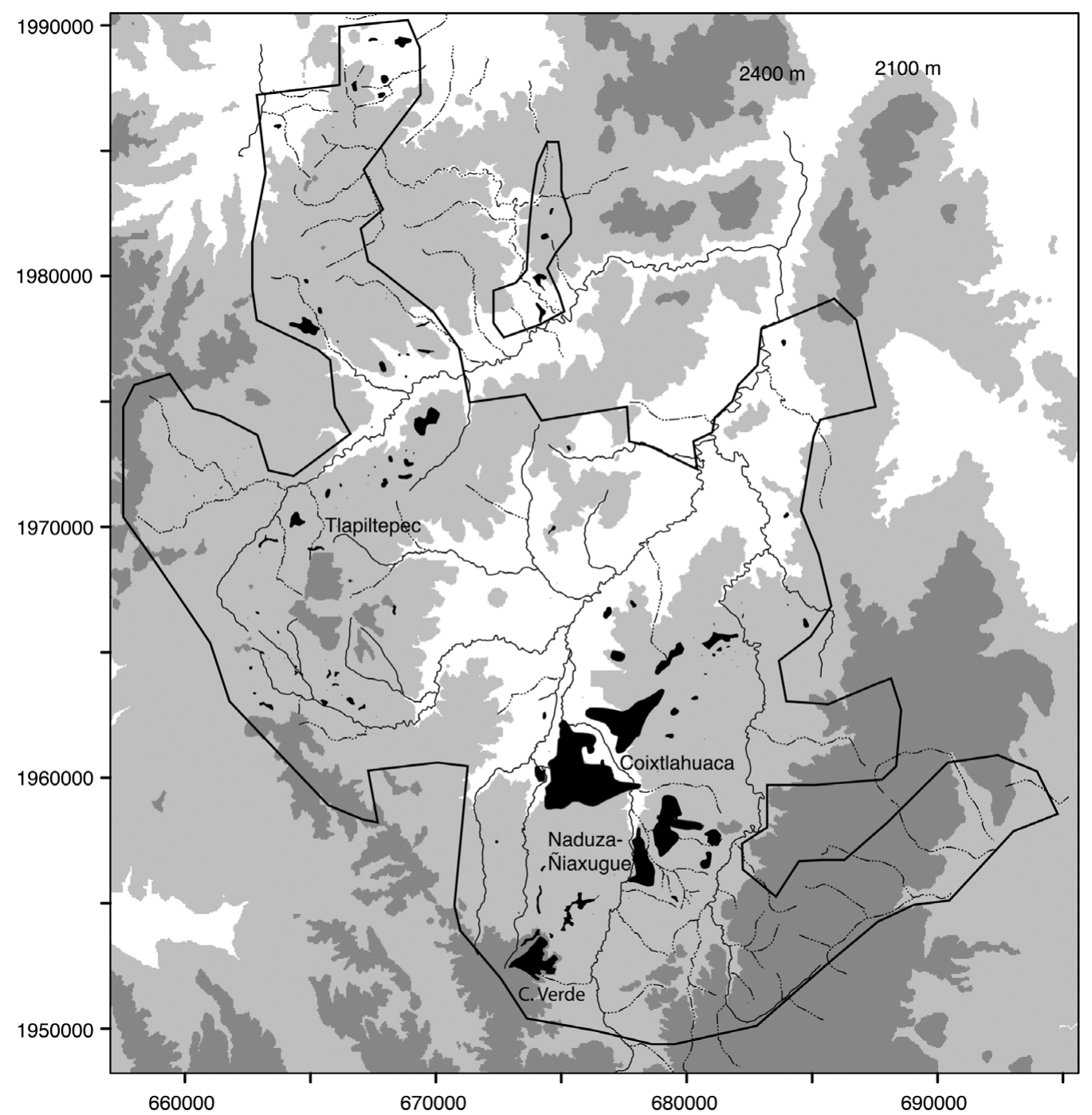

Figure 4. Early Las Flores (AD 200-600) settlements in the valley of Coixtlahuaca.

time-sensitive styles occur in Coixtlahuaca, the central Mixteca Alta, and the Valley of Oaxaca throughout the Formative. Contemporary pottery assemblages from Naduza-Niaxugue are equal in quality and frequency of decoration to those from the Valley of Oaxaca, and many examples could serve as type illustrations in the standard work on Monte Albán ceramics (Caso et al. 1967).

\section{Early Classic (AD 200-600)}

From about AD 200, people began settling at more places in the southern part of the valley (Figure 4). A new mountaintop town was founded at Cerro Verde. The northern half of the valley was only lightly and ephemerally settled, and was probably a political frontier.

We identified some surface collections as Terminal Formative-Early Classic Transition (Caso et al. 1967; Stiver 2001). Other collections, especially small ones, are ambiguous and are assigned to Early Las Flores. Collections with Transition attributes come from the southern valley, at Cerro Verde and Coixtlahuaca, so it is likely that the growth in settlement began first in that area.

Cerro Verde (Nudo Mixteco) is the divide between the Pacific-draining Ríos Balsas and Verde, and the Gulf-draining Río Papaloapan. 
Settlement was on the peaks, ridges, and slopes east of Cerro Verde, $500 \mathrm{~m}$ above and $2 \mathrm{~km}$ distant from the valley floor. We recorded 678 stone terrace walls, the total length of which is 31.7 $\mathrm{km}$. Most terraces were residential but some were built as ramps or defensive walls, for planting, or to stabilize slopes. Settlement began in the Transition period and spread to cover a maximum of 197 ha in the Early Classic. We identified no Late Classic or Early Postclassic settlements in this region.

The distribution of civic-ceremonial architecture (CCA) at Early Classic Cerro Verde is decidedly noncentralized. Modest-sized platform mounds occur on six different peaks and one saddle. One group has three mounds, one has two, and five have one. Small plazas are at each of these groups and on two other peaks. The town thus looks like a collection of barrios, a pattern found elsewhere in the Mixteca Alta (Kowalewski et al. 2009; Stiver 2001).

The town of Naduza-Niaxugue continued to be densely settled and was a secondary center to Cerro Verde. Founded by 700 BC, it was the longest continuously occupied settlement in the region.

The settlement pattern in the southern Coixtlahuaca valley has a form similar to the contemporaneous polities in the central Mixteca Alta: a territory of $50-150 \mathrm{~km}^{2}$; a population of 5,000-15,000 inhabitants; a civic-ceremonial center, usually on a high, defendable mountain; secondary centers or barrios with public buildings at lower elevations; and a variety of settlements close to the valley floor. This pattern was interpreted as the $\tilde{n} u u$, the Mixtec term for the small state (Kowalewski et al. 2009:305314). In Chocholtec, the corresponding term is saçê (see below).

Late Classic, Epiclassic, and Early Postclassic (AD 600-1200)

The Late Classic is problematic in the Mixteca Alta. Excavations at Yucuñudahui (Caso 1938; Spores 1974) and Yucundaa (Spores and Robles García 2014) found abundant Early Classic and Late Postclassic occupation, but Late Classic and Early Postclassic contexts are rare and not well documented. Radiocarbon dates are lacking. The nearest place with substantial assemblages in the
AD 600-1000 time range is Peñoles in the eastern Mixteca Alta (Finsten 1996).

In 19 of our collections, we found sherds similar to a ware identified in Veracruz, Puebla, and elsewhere in Oaxaca as metálica or false plumbate, which should date to about AD 1000 (Bey and Ringle 2007; Fahmel 1988). Pastes are fine-tempered, hard, and fired orange; surfaces are slipped dark gray and burnished, with pre-firing incising of medium-width simple lines or post-firing thin lines scratched through the slip. Vessels are mostly bowls-slightly outleaning, cylindrical, or barrel-shaped-and rims are simple and direct. Further work may be able to identify co-occurring wares.

Figure 5 shows that collections having metálica sherds are widespread, but none are from the Coixtlahuaca urban center. Tentatively we suggest a repopulation of the valley in Early Postclassic times. Sites where metálica occurs are generally small and located on hilltops in the upper reaches of drainages, a situation suited for small populations lacking the labor to maintain terrace systems covering whole basins. This scenario requires testing.

\section{Late Postclassic (AD 1200-1520)}

This was the time of heaviest occupation (Figure 6). We mapped 10,215 ha of settlement. Society was at its most urbanized; rural economic development was greater than at any time before or since.

Some Late Postclassic sites are remarkably extensive. The city of Coixtlahuaca has an unbroken spread of Late Postclassic artifacts covering $30 \mathrm{~km}^{2}$, not counting nearby barrios such as the $6 \mathrm{~km}^{2}$ of Suchixtlahuaca. The central sectors alone of Tequixtepec and Ihuitlán covered $9 \mathrm{~km}^{2}$ each. Essentially the whole valley of Tulancingo is one archaeological site of $8 \mathrm{~km}^{2}$. To give an idea of demographic scale, a density of 10 to 25 persons per hectare (compact low-density village in the Basin of Mexico [Sanders et al. 1979:38-39] and the range used most frequently in highland Oaxaca surveys [Kowalewski et al. 1989:35]) would yield a range of 100,000 to 250,000 people in the valley of Coixtlahuaca, 10 to 25 times the population today. Further refinements in population estimates could be made by considering sites of higher density 


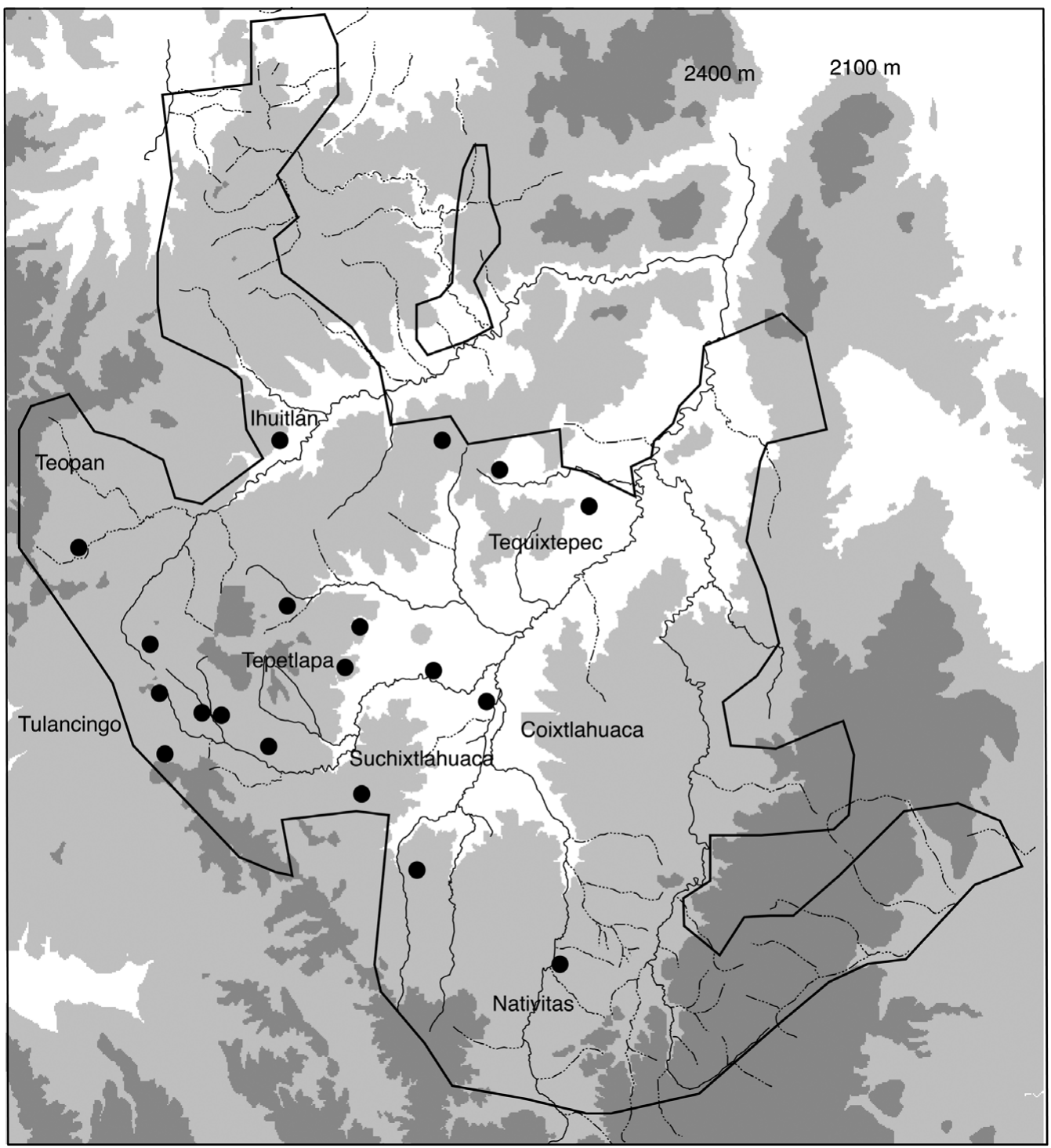

Figure 5. Surface collections having metálica or false plumbate, a possible Early Postclassic marker.

(Coixtlahuaca itself, for one) and issues of absolute contemporaneity.

The Mixteca Alta as a whole was quite urbanized and the Coixtlahuaca valley even more so. About $85 \%$ of its population lived in settlements greater than 40 ha. Using an urban threshold of 100 ha (1,000 to 2,500 people), the urbanization rate would be $77 \%$, which is high compared to other urban societies historically (de Vries 1984).

The largest sites were urban in physical and demographic size. They were top-ranked central places in a system of cities that extended well beyond this valley. But what portion of their inhabitants was engaged in providing goods and services not found in other places? How socially heterogeneous were these centers? Was this an "agrarian urbanism" (Kowalewski et al. 2009:346-348)? Our systematic surface collections at Coixtlahuaca identified no zones of specialized production nor any obviously poor sectors. There was a fair degree of cost-uniformity in household refuse over the city, rather than concentration of wealth in the center (Steere and Kowalewski 2012). Our study was only a 


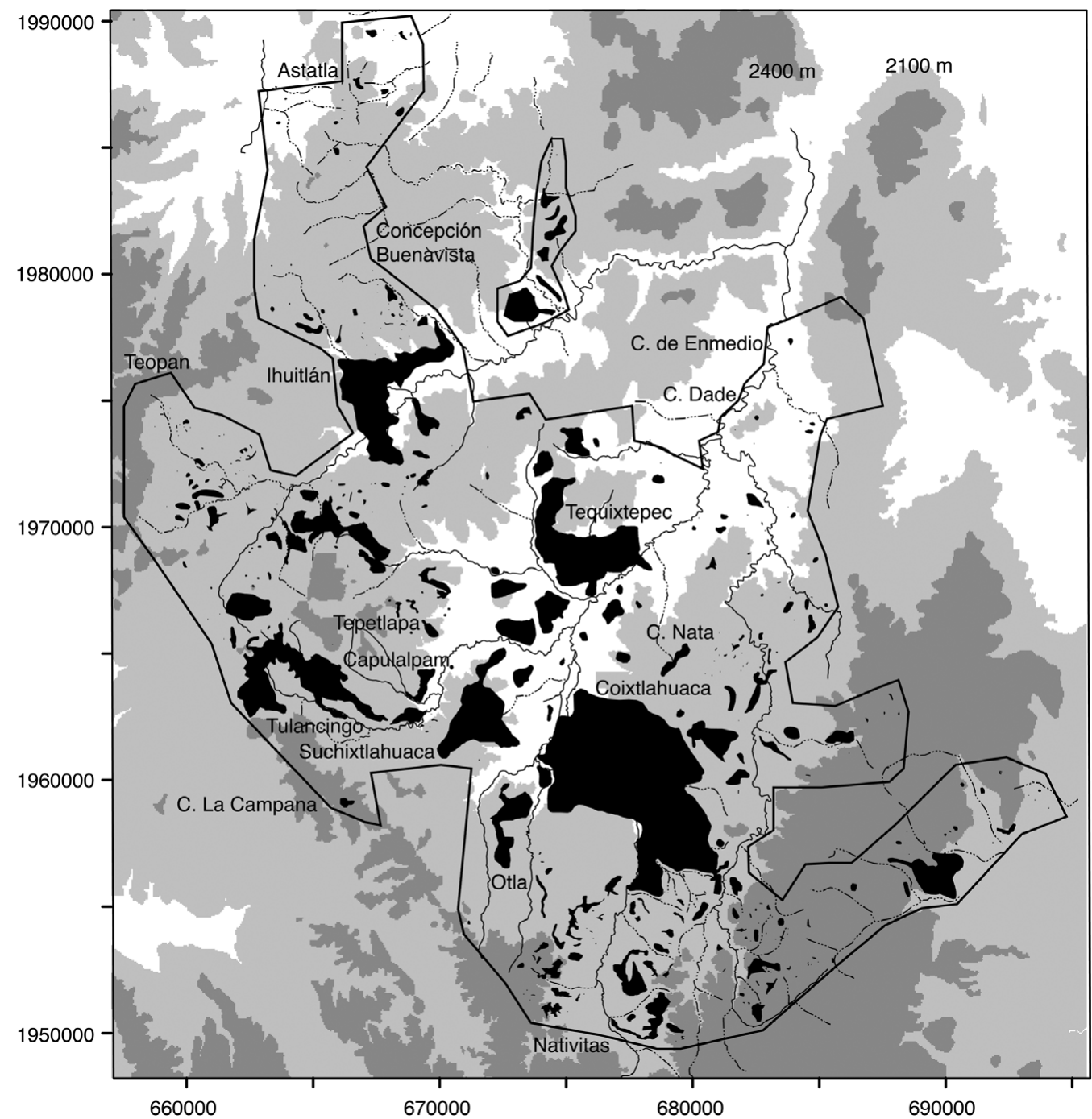

Figure 6. Late Natividad (AD 1200-1520) settlements in the valley of Coixtlahuaca.

first step, and surface collections are not sufficient in themselves to answer these complex questions.

Were these places just overgrown villages? Did people have milpas next to their houses? Perhaps, but the residential density was such that the urban space was not sufficient to provide the amount of food required. Most of the urban dwellers may have been farming outside the city limits, as in traditional Yoruba cities, but the rural areas were already heavily populated and city residents would have been competing for land with many thousands of rural people (Figure 6).
What activities and functions went on in cities such as Coixtlahuaca, especially at the household level? This is a broader, Mesoamericawide problem brought to light when systematic surveys began documenting the scale of cities and the character of their hinterlands.

The Late Postclassic saw intensive rural development. Settlements were distributed so as to locate farmers near the fields that required the most labor and attention. This meant a dispersed settlement pattern $-81 \%$ of sites (325) were less than 10 ha in size. Rural settlements were more dispersed in some drainages and more nucleated in others. In the Teopan tributary, we found 
44 sites totaling 93 ha; Concepción Buenavista, outside the city of Ihuitlán, had 51 sites totaling 87 ha. Nativitas had 41 sites totaling 487 ha, including two of 113 ha each. Coixtlahuaca's immediate hinterland had the same pattern of numerous hamlets and small villages plus seven midsize places of 40 to 200 ha or more.

Smallholders and communities were embedded in a large-scale commercial economy. Sixteenth-century sources tell of a major international market in Coixtlahuaca (Códice Chimalpopoca 1945; Durán 1967:2:185-195), and there were other markets as well (van Doesburg 2002). Given the large population and degree of urbanization, undoubtedly there was a high degree of market dependence. Comparative urban and rural household studies are needed to document this economy.

Evidence of specialized production and distribution of goods is limited. We identified two andesite quarry-workshops for making manos and metates (one at Cerro Nata covers $2 \mathrm{ha}$ ) and several sites used for chert working. All obsidian was imported and most was recovered from Late Postclassic contexts. Obsidian densities are higher in the city of Coixtlahuaca than in other places, but obsidian is widely distributed across all neighborhoods. We found none of the standard evidence for places of pottery making, yet the quantities of ceramic refuse are astounding. In historic times, pottery-making villages in the Mixteca Alta were not located in the wide and fertile valleys but in more agriculturally marginal places such as Tonaltepec, just outside our survey area. One hypothesis is that potters and farmers were engaged in market exchange in which there were zones of specialization, following the principle of comparative advantage (Kowalewski 2016).

The CCA is revealing in several respects (Figure 7). Our analysis attempts to capture public buildings as opposed to ordinary domestic structures. Our criteria are size, a platform greater than $1 \mathrm{~m}$ in height, and placement in a prominent position or association with a plaza. The top of the platform reflects the potential size and form of the building it once supported. Platform tops are distributed in three classes: "small" $(n=49)$ have tops less than $10 \mathrm{~m}$ in length (the smallest is $\left.24 \mathrm{~m}^{2}\right)$; "medium" $(n=32)$ have one dimension greater than $10 \mathrm{~m}$ but top areas less than 200 $\mathrm{m}^{2}$; and "large" $(n=26)$ have top areas greater than $200 \mathrm{~m}^{2}$. Dating is by associated ceramics from the surface or from exposed fill, thus "Late Postclassic" may mean platform construction or continued use of an earlier platform. Structures that we could not date by associated sherds, such as two small platforms on the Cerro Verde peak, are not included here. By these criteria the CCA count is 107. The "?" symbol in Figure 7 indicates places where public buildings probably existed but are obscured, such as under the sixteenth-century Convento de San Juan Bautista Coixtlahuaca.

The Valley of Coixtlahuaca has relatively few CCA structures. The count is only a quarter of that in the central Mixteca Alta (Kowalewski et al. 2009:412-483). Its major center has fewer platform mounds than the Pueblo Viejo at Teposcolula, a much smaller city (Stiver 2001:93).

The platforms are small. The tallest is $7 \mathrm{~m}$ high. The largest are smaller than their contemporaries in the central Mixteca Alta and the Valley of Oaxaca. The small number of platforms and their small size is characteristic of the entire Coixtlahuaca sequence after the Formative. Public architecture of imposing dimensions concentrates labor, symbolic meaning, and psychological effect in singular, central places (e.g., Burger and Rosenswig 2012). This concentration was weak in the valley of Coixtlahuaca. Yet there was a built environment that was imposing, full of symbolic meaning, and perhaps psychologically moving - the completely terraced, monumental landscape (cf. Conklin 1980).

Platforms tend to be widely distributed rather than built in one central place. The CCA evidence suggests that cities and towns were aggregates of barrios rather than distinctive places integrated by dominant central institutions. At the regional capital, 19 of the 32 platforms are scattered in outlying sectors and 13 are in a central precinct. The city of Tequixtepec had three major barrios, each with CCA, and even in these three sectors the buildings were not all grouped in one place. Nativitas and Suchixtlahuaca are other large settlements with the same pattern of a few public buildings scattered in different sectors. At the city of Ihuitlán, we recorded a single place that 


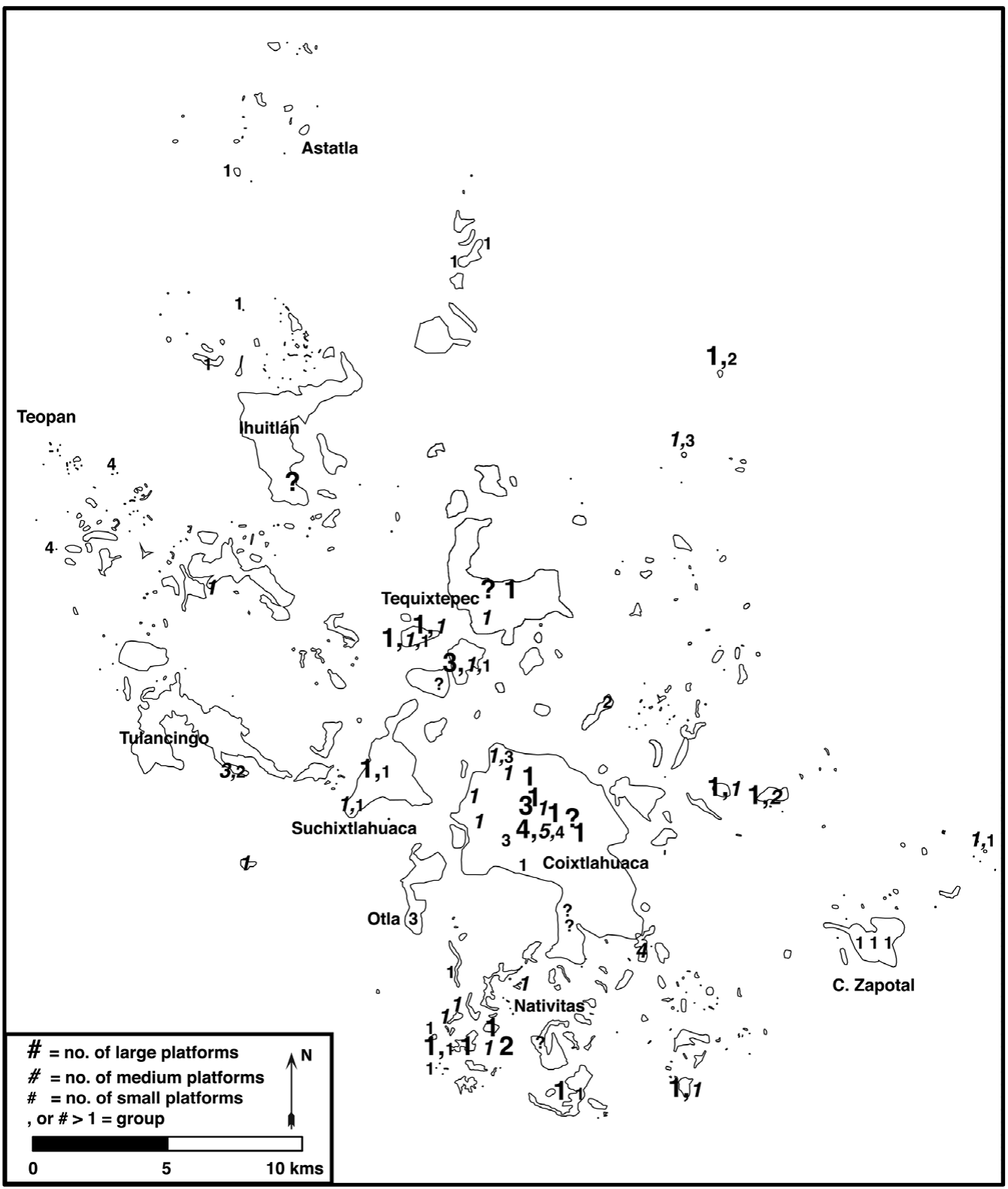

Figure 7. Distribution of Late Postclassic platform mounds for civic-ceremonial buildings, by size class, with outlines of Late Postclassic settlements. Numbers refer to number of mounds in a size class in a group at a specific place. Groups are indicated by numbers greater than one and by strings separated by commas. Platform size classes: largest have top areas $>200 \mathrm{~m}^{2}$, shown with a number in the largest font size; medium have top areas $<200 \mathrm{~m}$ and top lengths $>10 \mathrm{~m}$, shown with a number in medium-size italic font; and small have tops with no dimension $>10 \mathrm{~m}$ but are considered to be public buildings, shown with number in smallest font. Positions of numbers approximate locations. For example, in the center of Coixtlahuaca is a group of 4 large, 5 medium, and 4 small platforms. Cerro Zapotal, southeast of Coixtlahuaca, has 3 small mounds at 3 different places.

had perhaps two platforms. Tulancingo likewise had little Postclassic public construction apart from an unusual group of five small platforms atop the Loma Tortolita (turtle dove), which may be the ritual place depicted on the Lienzo de Tlapiltepec and the Lienzo Seler II/Coixtlahuaca II (Brownstone 2015:111, 121), as suggested by van Doesburg (2004). 
Small groups of buildings on hilltops mark the edges of territories. For example, the edges of the small valley at Teopan have two nearly identical four-mound-and-patio groups. Similar groups are found in the central Mixteca Alta and in the Valley of Oaxaca, so this is a pattern that crossed regional and linguistic lines. Northeast of Tequixtepec, the Cerro Dade (hill of the market in Chocholtec) and Cerro de Enmedio, both defensible, have formal mound groups. A single small platform in an enclosure was built on the summit of the fortified Cerro de La Campana south of Tulancingo. The limits of some large settlements also may be marked by mound groups. Coixtlahuaca has four-mound groups at its north and south ends, and its major barrio of Suchixtlahuaca to the west has two formal groups.

It is not clear what scale of territory or organization these boundary sites may have marked. Each potentially pertained to a local territorial organization; for example, Teopan could have had an eastern and a western barrio. Or a ruling house might have placed a cadet lineage at some remove from itself, in which case the group of buildings, say the three at Otla, would be a branch pertaining to a ruling dynasty.

\section{Terracing and Land Tenure}

It has long been known that farmers in the Mixteca Alta covered the land with cross-channel (lama-bordo) and contour terraces to retain and build up soil and moisture. Terraced fields, especially lama-bordos, were more productive than extensive rainfall-dependent fields (Spores and Balkansky 2013:8-79, 108-109). In the banks of down-cut arroyos we recorded 284 ancient check dams. This number is almost meaningless because we could not search for them systematically and many that once existed are now buried or eroded away. A more methodical search by Leigh and Holdridge found 50 on a single stream (Leigh et al. 2013). Every inhabited stream drainage had chains of check dams.

Identifying ancient hillside terraces is more problematic. Farmers constantly shift the stone walls to cope with soil movement and changing land tenure, so the terraces in places with active fields are recent creations. Slopes where fields were abandoned in the past have been scoured by sheet and gulley erosion. Recent reforestation projects further modify slopes.

The experience of recent farmers teaches us two key principles. First, terraces and check dams are made and maintained by small, usually household task-groups (Pérez Rodríguez 2006). Second, because unchecked floodwaters are destructive, a whole drainage segment has to be managed - the hillsides as well as the stream. Therefore, check dams are made in conjunction with contour terraces, beginning at the heads of drainages, not at the midpoint or downstream. These two principles, smallholder labor and whole-drainage management, have implications for social organization.

Investment of labor in landesque capital, that is, investment in long-term material improvements to land (Håkansson and Widgren 2014), apparently began in the Early Formative. A commitment of many cooperating households must have been the key to the Neolithic revolution in this part of Mesoamerica. Why the investment of labor in terracing? With these fertile but erodible soils, erratic rains, and sloping terrain, terracing would be the best way to farm under most conditions of population density or market demand. It was not a technological innovation made reluctantly under conditions of population pressure after a long period of extensive farming (Boserup 1966), but a practical solution for normal risk management, in use almost from the beginning. The agricultural consequence of this commitment was high yield. The population consequence was a positive feedback loop between higher yields and a larger labor force.

Some researchers (Barker 2002; Håkansson 2014; Loiske 2004) have associated landesque capital with world-system demands. The idea is that farmers will not intensify their labor if they do not need cash or there is no external market demand for their output. We are open to considering market demand from the Mesoamerican world-system as one factor promoting landesque capital. The external demands would likely have had to do with the textile sector (cf. Stark et al. 2016). Nonetheless, it seems probable that most market demand was endogenous, coming from the Mixteca Alta and its nearby trading partners. 
Apart from the origin of demand, landesque capital studies have observed regularities in property and land tenure. In general, small farmers will not invest their own labor in land improvements if they do not have some assurance of long-term tenure (Brookfield 1984). For example, sharecroppers on year-to-year contracts may work hard to sow and reap as much as they can, but they have no interest in picking up stones (Svensson 2014). Sixteenth-century wills from Tulancingo in the valley of Coixtlahuaca show that smallholders did have long-term, heritable rights to their fields (van Doesburg 2004). An implication would be that the tay situndayu (the Mixtec term for landless laborers) would have been a small proportion of the commoner class in places with intensive agricultural terracing. We cannot see the form of property archaeologically, but the intensive rural development is consistent with the historical evidence for smallholder control. Future archaeological study of households could measure relative economic wealth and degree of permanence (Pérez Rodríguez 2006).

Local communities and landesque capital have a long history in Coixtlahuaca. Yet there is a paradox: the population experienced highamplitude swings of growth and decline, cycles that coincide with demographic rise and decline elsewhere in highland Oaxaca. Periods of great growth and decline are hardly uncommon in the archaeological record in Mesoamerica or on other continents. We are not yet able to account for such cycles at Coixtlahuaca. One factor that could account for the higher amplitude in this broad valley, as opposed to the small valleys, is the positive feedback loop of intensive agriculture-demand-population growth. This loop may have been hard to initiate (as it would be today), but when operating, it could be powerful and self-sustaining. Nevertheless, it was vulnerable to rapid collapse, conceivably from external military force and certainly from an entirely exogenous factor such as European diseases (cf. Brookfield 1986; Widgren 2007).

\section{¿Cómo se Organizaron?}

The commitment to landesque capital by smallholders shaped social organization and religion.
In sixteenth-century Coixtlahuaca, smallholder households were organized in barrios (sindi in Chocholtec) that controlled and allocated rights to use and inherit fields (van Doesburg 2004; van Doesburg and Swanton 2011). Sindi were territorial and participatory, and their lands coincided with a segment of a stream drainage. Territories were marked by shrines or temples. Sindi were corporate in this sense, but there is no evidence that they were corporate descent groups.

Sindi were sections of communities (saçê; Spanish pueblo), the minimal state corresponding to ñuu or altepetl (van Doesburg and Swanton 2011). The saçê had a territory that corresponded to a drainage basin. That is, barrios were situated along adjacent first-order streams. Communities ( $\operatorname{saçê)~encompassed~several~of~these~and~included~}$ a downstream, second-order reach. This is idealized, but the logic is that the labor and capital in the land were situated in specific stream basins.

A concrete example can be traced along the stream from Tulancingo to Tequixtepec, where each community was in its own basin separated from its neighbors by a divide. The Río Grande de Tulancingo heads at the western end of the valley, and the first community was Tulancingo, consisting of several barrios along the stream and its tributaries. Tulancingo is separated from the next community to the east, Suchixtlahuaca, as the two are in different drainage basins. Down the Río Grande are two smaller communities, Capulalpam and Tepetlapa, each centered on a permanent tributary stream. These two are very small places now, but in the Postclassic each had several barrios. Farther downstream, the Río Grande is joined by two important tributaries at the community of Tequixtepec. Here as elsewhere in the valley, larger towns are on the downstream reaches and smaller ones are upstream. As the Río Grande descends east of Tequixtepec, it flows through narrow valleys and its water is mostly inaccessible for farming. The Tequixtepec border sites (Cerro Dade and Cerro de Enmedio) are at the point where the river drops into a steep and rocky gorge.

In Late Postclassic and probably earlier times, a similar nexus bound together intensive agriculture, smallholders, strong communities, ritual, and institutions analogous to the historic tequio and faena (community collective work service), 
as Carballo (2013b) notes for central Mexico. Noble lords and ladies, through their marriage alliances, conquests, and other deals, could have holdings in various places, and in this sense the city-state was not necessarily territorial (Hirth 2003; Romero Frizzi 1996; Terraciano 2001). But from the point of view of commoners, the saçê was a specific physical space. This tangle of local and cacique interests added fuel to territorial disputes that continued after the colonial period (Dennis 1987; Mendoza García 2005). The entire valley and some places beyond were drawn together by alliance or conquest in a greater state (curhuña) headed by Coixtlahuaca (van Doesburg and Swanton 2011). Coixtlahuaca, Tequixtepec, Ihuitlán, and Tulancingo, in that order, were the main centers, followed by tiers of secondary centers (e.g., Suchixtlahuaca, Nativitas) and tertiary centers (e.g., Capulalpam, Nata).

The lienzos show the names and locations of subject towns and barrios, many of which can be identified as specific clusters of archaeological sites. Prehispanic, pre-congregación Otla, Suchixtlahuaca, Nativitas, Tequixtepec, and most of the barrios of Ihuitlán (Brownstone 2015) are now identifiable on the ground. Other communities seen archaeologically have not yet been identified on lienzos. In some cases, the palaces or temples shown on the lienzos are specific, known archaeological places, as at Coixtlahuaca, Tequixtepec, Nativitas, Otla, and Tulancingo.

Organization tended to be segmentary at all levels. Cities and smaller communities were aggregations of barrios and centralization was weak. We think this was due to the inwardfacing, localizing tendencies of the communal landholding units. The noble class tended to segment by descent and marriage alliance, and did not develop much bureaucracy (Lind 2000). A distinctive feature of government detailed in the Coixtlahuaca lienzos is that the large centers had not one but several ruling lineages. Coixtlahuaca had two major ruling lineages, each with its palace-temple (e.g., Caso 1977:1:118136) on opposite sides of the river about the center of the city. There was a lesser noble palacetemple at the north edge of the city. Tequixtepec likewise was composed of several ruling houses, according to the lienzos and sixteenth-century documents (Rincón Mautner 2007, 2012; van Doesburg 2002, 2010; van Doesburg and van Buren 1997). This feature of multiple ruling lineages in one city closely parallels the earlier description above, showing that the CCA were distributed in multiple places instead of being concentrated in single areas.

Each of these three levels-sindi, saçê, and curhuña-has archaeological correlates. Sindi are clusters of settlement located along drainage segments. Often there are hilltop shrines or temples, or settlements on hills at the edges of the barrio. Saçê are clusters of barrios along the same stream drainage, usually with a few public buildings distributed in the larger barrios. The curhuña is seen archaeologically in the settlement hierarchy of the whole valley. The hierarchy of public buildings by number and size also reflects the organization of the curhuña.

\section{Conclusion}

Full-coverage regional survey is an essential step toward understanding local and macroregional processes. The RAC project made improvements in efficiency, data management, and public education over similar previous surveys. It did not achieve all its goals in the extent of area surveyed or quality and richness of information. We recommend that regional survey designs take into account both the improvements we made and the deficiencies of the research design. Many difficulties might be avoided by attending to project management and by building flexibility and capacity into the budget at the proposal stage.

The archaeological record of the Coixtlahuaca valley is enormous. One site on the Río Grande de Ihuitlán extends unbroken for $14 \mathrm{~km}$, and it is not the largest. That distinction belongs to Coixtlahuaca, at $30 \mathrm{~km}^{2}$. The valley of Coixtlahuaca has some of the largest Middle Formative sites reported (one is $13 \mathrm{~km}^{2}$ ). Artifacts are often abundant. The valley had neither big buildings nor stelae, and even the wealthy and powerful were stuffed into tombs less than a meter in diameter (Bernal 1948-1949). The real monument of Coixtlahuaca was its completely terraced landscape, a spatially and temporally distributed 
work that in its aggregate was far larger than the pyramids of Teotihuacan.

The survey provides on-the-ground context for ethnohistorical accounts. Aztec sources (e.g., Durán 1967:2:185) speak of the major international market at Coixtlahuaca. The physical marketplace has not been located, although there are possibilities that might be investigated. A conquest of Coixtlahuaca by Motecuhzoma I was chronicled by the Aztecs (e. g., Códice Chimalpopoca 1945:52). Nonetheless, the archaeological imprint of Aztec presence seems minimal (Kowalewski et al. 2010).

The richest ethnohistorical sources are local and consist of the lienzos and some sixteenthcentury texts in archives. Our archaeological survey is in accord with the lienzos, often in specific detail regarding named places, hierarchy, and the segmentary character of the state. There is one important point on which the lienzos are totally silent, and that is the demographic and urban scale of society. This is true of royal dynastic texts elsewhere, too. When one sees the graphic image of lords carrying out a ritual at a place named Tulancingo, one has no idea that it was a city $9 \mathrm{~km}$ long, covering the whole Tulancingo valley. The archaeology suggests that 200,000 people was the approximate magnitude of Late Postclassic Coixtlahuaca regional society.

We have described how a population of this size was organized in the Late Postclassic. Key elements of this organization are older. Crossdrainage check dams dated to $1500 \mathrm{BC}$ indicate an early age for the social commitment to terrace systems. Investment in landesque capital increased in the Middle Formative, when we also see local communities centered on drainage basins and shrines or temples at the boundaries of territories. The pattern of few, small, and widely distributed rather than centrally concentrated civic-ceremonial buildings began in the Middle Formative. The city-state seems to have been present in the Early Classic, but almost nothing is known about political organization above the level of the local community in the Middle Formative. In this "moment" of Mixteca Alta society, local communities organize themselves.

Important structural features have persisted over the longue durée: the strong linkage between smallholders and intensive terrace agriculture; cooperating, territorially based barrios and local communities; localist religion; and resistance to centralizing authority. These persistent structural features are maintained through collective action drawing on internally generated resources (Blanton and Fargher 2008).

Persistence of the collective community does not translate into collective action for society as a whole. The state had greater access to external resources, supra-local authority, and military power. Kings employed aggrandizing, individualizing network strategies; they appropriated land and people (well attested in the sixteenth century as the system was collapsing, e.g., Spores 2007; Terraciano 2001). This was the moment of Mixteca Alta society emphasized by Fargher et al. (2011).

Society as a whole is neither self-organized nor organized by rulers. Mutually dependent, competing classes have distinct interests and strategies. In the Mixteca Alta the dialectic between rulers and the collective agency of commoners was itself a persistent structural feature, and this case is not unique. Balinese history displays a similar struggle between rulers with external resources and communities that generated internal resources through a self-governing agroecosystem (Covarrubias 1956; Geertz 1980; Lansing 1995). Returning to the question asked by Coixtlahuacans about how people were organized in the past, and in light of what we have learned, we observe that the problems and strategies, although not identical to those of today, were sufficiently similar as to make the answers interesting.

Acknowledgments. The 2011 RAC project was supported by the National Science Foundation and the Fundación Harp Helú, with permission of the Instituto Nacional de Antropología e Historia (INAH) and the helpful actions of the Centro INAH Oaxaca. We thank Agustín Andrade Cuautle, Alberto Bazán Hernández, Leonardo Bazán Velasco, Luis Cruz Lara, Sebastián van Doesburg, Fernando Juárez, Gustavo Salazar, Ron Spores, Marijke Stoll, Mark Williams, Marc Winter, four reviewers, and hundreds of other people for their assistance. Many people taught us about how soil and water can be managed and how agricultural practices are embedded in society and tradition, but in particular we credit the expertise of Baldemar García Lara, Guillermo Pérez Jerónimo, and Gil Heriberto Santiago Cruz. 
Data Availability Statement. Artifacts are curated by the Instituto Nacional de Antropología e Historia at the Convento San Juan Bautista Coixtlahuaca. Data are available from Stephen A. Kowalewski, Laboratory of Archaeology, Department of Anthropology, University of Georgia.

\section{References Cited}

Balkansky, Andrew K.

2006 Surveys and Mesoamerican Archaeology: The Emerging Macroregional Paradigm. Journal of Archaeological Research 14:53-95.

Barker, Graeme

2002 A Tale of Two Deserts: Contrasting Desertification Histories on Rome's Desert Frontiers. World Archaeology 33:488-507.

Bernal, Ignacio

1948-1949 Exploraciones en Coixtlahuaca, Oax. Revista Mexicana de Estudios Antropológicos 10:5-76.

Bey III, George J., and William M. Ringle

2007 From the Bottom Up: The Timing and Nature of the Tula Chichén Itzá Exchange. In Twin Tollans: Chichén Itzá, Tula and the Epiclassic to Early Postclassic Mesoamerican World, edited by Jeff Karl Kowalski and Cynthia Kristian-Graham, pp. 377-428. Dumbarton Oaks, Washington, DC.

Blanton, Richard, and Lane Fargher

2008 Collective Action in the Formation of Pre-Modern States. Springer, New York.

Blomster, Jeffrey P.

2004 Etlatongo: Social Complexity, Interaction, and Village Life in the Mixteca Alta of Oaxaca, Mexico. Thomson Wadsworth, Belmont, California.

Boserup, Esther

1966 The Conditions of Agricultural Growth: The Economics of Agrarian Change under Population Pressure. Aldine, Chicago.

Brookfield, Harold S.

1984 Intensification Revisited. Pacific Viewpoint 25:1544.

1986 Intensification Intensified. Archaeology in Oceania 31:177-180.

Brownstone, Arni (editor)

2015 The Lienzo of Tlapiltepec: A Painted History from the Northern Mixteca. University of Oklahoma Press, Norman.

Burger, Richard L., and Robert M. Rosenswig (editors)

2012 Early Mesoamerican Monumentality. University Press of Florida, Gainesville.

Byland, Bruce E.

1980 Political and Economic Evolution in the Tamazulapan Valley, Mixteca Alta, Oaxaca, México: A Regional Approach. PhD dissertation, Department of Anthropology, Pennsylvania State University, University Park, Pennsylvania.

Carballo, David M. (editor)

2013a Cooperation and Collective Action: Archaeological Perspectives. University Press of Colorado, Boulder.

2013b Labor Collectives and Group Cooperation in PreHispanic Central Mexico. In Cooperation and Collective Action: Archaeological Perspectives, edited by
David M. Carballo, pp. 243-274. University Press of Colorado, Boulder.

Caso, Alfonso

1938 Exploraciones en Oaxaca, Quinta y Sexta Temporadas, 1936-1937. Publicación 34. Instituto Panamericano de Geografía e Historia, Mexico City.

1977 Reyes y reinos de la Mixteca. 2 vols. Fondo de Cultural Económica, Mexico City.

Caso, Alfonso, Ignacio Bernal, and Jorge R. Acosta

1967 La cerámica de Monte Albán. Memorias 13. Instituto Nacional de Antropología e Historia, Mexico City.

Códice, Chimalpopoca

1945 Códice Chimalpopoca: Anales de Cuauhtitlán y leyenda de los soles. Translated by Primo Feliciano Velázquez. Universidad Nacional Autónoma de México, Mexico City.

Conklin, Harold S.

1980 Ethnographic Atlas of Ifugao: A Study of Environment, Culture, and Society in Northern Luzon. Yale University Press, New Haven, Connecticut.

Covarrubias, Miguel

1956 Island of Bali. Alfred A. Knopf, New York.

Dennis, Philip A.

1987 Inter-Village Conflict in Oaxaca. Rutgers University Press, New Brunswick, New Jersey.

de Vries, Jan

1984 European Urbanization 1500-1800. Harvard University Press, Cambridge, Massachusetts.

Drennan, Robert D.

1976 Fábrica San José and Middle Formative Society in the Valley of Oaxaca. Memoirs 8. Museum of Anthropology, University of Michigan, Ann Arbor.

Durán, Fray Diego de

1967 Historia de las Indias de Nueva España e islas de la Tierra Firme. 2 vols. Edited by Ángel Ma. Garibay K. Editorial Porrúa, Mexico City.

Fahmel Beyer, Bernd

1988 Mesoamérica tolteca: Sus cerámicas de comercio principales. Universidad Nacional Autónoma de México, Mexico City.

Fargher, Lane F., Verenice Y. Heredia Espinoza, and Richard E. Blanton

2011 Alternative Pathways to Power in Late Postclassic Highland Mesoamerica. Journal of Anthropological Archaeology 30:306-326.

Finsten, Laura

1996 Periphery and Frontier in Southern Mexico: The Mixtec Sierra in Highland Oaxaca. In PreColumbian World-Systems, edited by Peter N. Peregrine and Gary M. Feinman, pp. 77-96. Monographs in World Archaeology No. 26. Prehistory Press, Madison, Wisconsin.

Flannery, Kent V., and Joyce Marcus

1994 Early Formative Pottery of the Valley of Oaxaca. Memoirs 27. Museum of Anthropology, University of Michigan, Ann Arbor.

García Ayala, Gabriela

2011 Urbanismo en la Mixteca Alta, Oaxaca: El caso de Naduza-Ñiaxugue en la región de Coixtlahuaca. Tesis de Licenciatura, Escuela Nacional de Antropología e Historia, Mexico City.

Geertz, Clifford

1980 Negara: The Theatre State in Nineteenth-Century Bali. Princeton University Press, Princeton, New Jersey. 
Grosser Lerner, Eva

2004 El sapo y la culebra: Un mito chocholteco (Ngigua) (Prolegómenos a su análisis). Dimensión Antropológica 11(30):44-87.

Håkansson, N. Thomas

2014 World Systems Terraces: External Exchange and the Formation of Landesque Capital among the Ifugao, the Philippines. In Landesque Capital: The Historical Ecology of Enduring Landscape Modifications, edited by $\mathrm{N}$. Thomas Håkansson and Mats Widgren, pp. 98-116. Left Coast Press, Walnut Creek, California.

Håkansson, N. Thomas, and Mats Widgren (editors)

2014 Landesque Capital: The Historical Ecology of Enduring Landscape Modifications. Left Coast Press, Walnut Creek, California.

Hirth, Kenneth G.

2003 The Altepetl and Urban Structure in Prehispanic Mesoamerica. In Urbanism in Mesoamerica, Vol. 1, edited by William T. Sanders, Alba Guadalupe Mastache, and Robert H. Cobean, pp. 57-84. Instituto Nacional de Antropología e Historia and Pennsylvania State University, University Park and Mexico City.

Huesca, Irene, Manuel Esparza, and Luis Castañeda Guzmán (editors)

1984 Cuestionario de Don Antonio Bergoza y Jordán, obispo de Antequera a los señores curas de la diósesis. 3 vols. Documentos del Archivo 2. Archivo General del Estado de Oaxaca, Oaxaca, Mexico.

Jiménez García, Agustín

2000 Xadeë Nchaxï, el pueblo de la Virgen, Santa María Nativitias: Cuentos y leyendas nigigua-español. Printed by the author, Santa María Nativitas, Oaxaca, Mexico.

Kirkby, Michael

1972 The Physical Environment of the Nochixtlán Valley, Oaxaca. Publications in Anthropology No. 2. Vanderbilt University, Nashville, Tennessee.

Kowalewski, Stephen A.

2016 It Was the Economy, Stupid. In Alternative Pathways to Complexity: Households, Markets, World-Systems, and Political Economy; Essays Honoring the Legacy of Richard E. Blanton, edited by Lane F. Fargher and Verenice Y. Heredia Espinoza. University Press of Colorado, Boulder.

Kowalewski, Stephen A., Andrew K. Balkansky, Laura R. Stiver Walsh, Thomas J. Pluckhahn, John F. Chamblee, Verónica Pérez Rodríguez, Verenice Y. Heredia Espinoza, and Charlotte A. Smith

2009 Origins of the Nuu: Archaeology in the Mixteca Alta, Mexico. University Press of Colorado, Boulder.

Kowalewski, Stephen A., Luis Barba Pingarrón, Jorge Blancas Vázquez, Marisol Cortés Vilchis, Gabriela García Ayala, Leonardo López Zárate, Agustín Ortiz Butrón, Thomas J. Pluckhahn, Benjamin A. Steere, and Blanca Vilchis Flores

2011 Dos ciudades prehispánicas en Coixtlahuaca, Oaxaca. Cuadernos del Sur 16(30):93-111.

Kowalewski, Stephen A., Luis Barba Pingarrón, Gabriela García Ayala, Benjamin A. Steere, Jorge Blancas, Marisol Yadira Cortés Vilchis, Leonardo López Zárate, Agustín Ortiz, Thomas J. Pluckhahn, and Blanca Vilchis Flores

2010 La presencia azteca en Oaxaca: La provincia de Coixtlahuaca. Anales de Antropología 44:77103.

Kowalewski, Stephen A., Gary Feinman, Laura Finsten, Richard E. Blanton, and Linda Nicholas
1989 Monte Albán's Hinterland, Part II: Prehispanic Settlement Patterns in Tlacolula, Etla, and Ocotlan, the Valley of Oaxaca, Mexico. 2 vols. Memoirs No. 23. Museum of Anthropology, University of Michigan, Ann Arbor.

Lansing, John Stephen

1995 The Balinese. Harcourt Brace, Forth Worth, Texas.

Leigh, David S., Stephen A. Kowalewski, and Genevieve Holdridge

20133400 Years of Agricultural Engineering in Mesoamerica: Lama-Bordos of the Mixteca Alta, Oaxaca, Mexico. Journal of Archaeological Science 40:4107-4111.

Lind, Michael D.

2000 Mixtec City-States and Mixtec City-State Culture. In A Comparative Study of Thirty City-State Cultures: An Investigation Conducted by the Copenhagen Polis Centre, edited by Mogens Herman Hansen, pp. 567 580. Royal Danish Academy of Sciences and Letters, Copenhagen.

Loiske, Vesa-Matti

2004 Institutionalized Exchange as a Driving Force in Intensive Agriculture: An Iraqw Case Study. In Islands of Intensive Agriculture in Eastern Africa, edited by M. Widgren and J. E. G. Sutton, pp. 105-113. James Currey, London.

MacNeish, Richard S., Melvin L. Fowler, Angel García Cook, Frederick A. Peterson, Antoinette NelkenTerner, and James A. Neely

1972 The Prehistory of the Tehuacan Valley. Vol. 5, Excavations and Reconnaissance. University of Texas Press, Austin.

MacNeish, Richard S., Frederick A. Peterson, and Kent V. Flannery

1970 The Prehistory of the Tehuacan Valley. Vol. 3, Ceramics. University of Texas Press, Austin.

Mendoza García, J. Edgar

2005 Pueblos y cacicazgos: Conflicto por límites entre los estados de Puebla y Oaxaca, 1854-1908. In Reconociendo al pasado: Miradas históricas sobre Oaxaca, edited by Daniela Traffano, pp. 191-212. Centro de Investigaciones y Estudios Superiores en Antropología Social and Instituto de Investigaciones en Humanidades, Universidad Autónoma "Benito Juárez" de Oaxaca, Mexico City.

Pérez Rodríguez, Verónica

2006 States and Households: The Social Organization of Terrace Agriculture in Postclassic Mixteca Alta, Oaxaca, Mexico. Latin American Antiquity 17:3-22.

Plunket, Patricia Scarborough

1983 An Intensive Survey in the Yucuita Sector of the Nochixtlán Valley, Oaxaca, Mexico. PhD dissertation, Department of Anthropology, Tulane University, New Orleans. University Microfilms, Ann Arbor, Michigan.

Ramírez Barrera, Sandra Liliana

2014 La pintura rupestre en San Miguel Tequixtepec, Oaxaca: Memoria visual en la Mixteca Alta. Tesis de Maestría, Historia del Arte, Instituto de Investigaciones Estéticas, Facultad de Filosofía Y Letras, Universidad Nacional Autónoma de México, Mexico City. Electronic document, https://www.academia.edu/7558328/ La_pintura_rupestre_en_san_MIguel_Tequixtepec_ Oaxaca._Memoria_visual_en_la_Mixteca, accessed December 6, 2006.

Rincón Mautner, Carlos A.

1999 Man and the Environment in the Coixtlahuaca Basin of Northwestern Oaxaca, Mexico: Two Thousand Years 
of Historical Ecology. PhD dissertation, Department of Anthropology, University of Texas, Austin.

2005 The Pictographic Assemblage from the Colossal Natural Bridge on the Ndaxagua, Coixtlahuaca Basin, Western Mixteca Alta of Oaxaca. Ketzalcalli 2:2-69.

2007 A Study of the Lienzo de San Jerónimo Otla from the Coixtlahuaca Basin of Oaxaca, Mexico. Latin American Indian Literatures Journal 23:74-95.

2012 Linajes y casas señoriales de los tolteca-chichimeca de Coixtlahuaca en la Mixteca Alta de Oaxaca. In El poder compartido: Ensayos sobre la arqueología de orgnizaciones políticas segmentarias y oligárquicas, edited by Annick Daneels and Gerardo Gutiérrez Mendoza, pp. 115-172. Centro de Investigaciones y Estudios Superiores en Antropología Social y Colegio de Michoacán, Mexico City.

Romero Frizzi, María de los Angeles

1996 El sol y la cruz: Los pueblos indígenas de Oaxaca colonial. Centro de Investigaciones y Estudios Superiores en Antropología Social y Instituto Nacional Indigenista, Mexico City.

Sanders, William T., Jeffrey R. Parsons, and Robert S. Santley

1979 The Basin of Mexico: Ecological Processes in the Evolution of a Civilization. Academic Press, New York. Spores, Ronald

1969 Settlement, Farming Technology, and Environment in the Nochixtlán Valley. Science 166:557-569.

1972 An Archaeological Settlement Survey of the Nochixtlán Valley, Oaxaca. Publications in Anthropology No. 1. Vanderbilt University, Nashville, Tennessee.

1974 Stratigraphic Excavations in the Nochixtlan Valley, Oaxaca. Publications in Anthropology No. 11. Vanderbilt University, Nashville, Tennessee.

$2007 \tilde{N}$ uи Ñudzahui, la mixteca de Oaxaca: La evolución de la cultura mixteca desde los primeros pueblos preclásicos hasta la independencia. Instituto Estatal de Educación Pública de Oaxaca, Oaxaca, Mexico.

Spores, Ronald, and Andrew K. Balkansky

2013 The Mixtecs of Oaxaca: Ancient Times to the Present. University of Oklahoma Press, Norman.

Spores, Ronald, and Nelly M. Robles García (editors)

2014 Yucundaa: La ciudad mixteca y su transformación prehispánica-colonial. Insitituto Nacional de Antropología e Historia y Fundación Harp Helú, México City.

Stark, Barbara L., Matthew A. Boxt, Janine Gasco, Rebecca B. González Lauck, Jessica D. Hedgepeth Balkin, Arthur A. Joyce, Stacie M. King, Charles L.F. Knight, Robert Kruger, Marc N. Levine, Richard G. Lesure, Rebecca Mendelsohn, Marx Navarro-Castillo, Hector Neff, Michael Ohnersorgen, Christopher A. Pool, L. Mark Raab, Robert M. Rosenswig, Marcie Venter, Barbara Voorhies, David T. Williams, and Andrew Workinger

2016 Economic Growth in Mesoamerica: Obsidian Consumption in the Coastal Lowlands. Journal of Anthropological Archaeology 41:263-282.

Steere, Benjamin A., and Stephen A. Kowalewski

2012 Wealth Stratification in Ancient Mesoamerica. Social Evolution \& History 11(1):20-48.
Stiver, Laura R.

2001 Prehispanic Mixtec Settlement and State in the Teposcolula Valley of Oaxaca, Mexico. PhD dissertation, Department of Anthropology, Vanderbilt University, Nashville, Tennessee.

Svensson, Henrik

2014 "Stonescape": Farmers' Differential Willingness to Invest in Landesque Capital in Nineteenth Century Sweden. In Landesque Capital: The Historical Ecology of Enduring Landscape Modifications, edited by $\mathrm{N}$. Thomas Håkansson and Mats Widgren, pp. 141-154. Left Coast Press, Walnut Creek, California.

Terraciano, Kevin

2001 The Mixtecs of Colonial Oaxaca: Nudzahui History, Sixteenth through Eighteenth Centuries. Stanford University Press, Stanford, California.

Urcid, Javier

2004 Sacred Landscapes and Social Memory: The Nuiñe Inscriptions in the Ndaxagua Natural Tunnel, Tepelmeme, Oaxaca. Report to the Foundation for the Advancement of Mesoamerican Studies. Electronic document, http://www.famsi.org/cgi-bin/print_ friendly.pl?file=03068, accessed November 13, 2006.

van Doesburg, Sebastián

2001 De linderos y lugares: Territorio y asentamiento en el Lienzo de Santa María Nativitas. Relaciones 22(86):1582.

2002 Documentos antiguos de San Miguel Tequixtepec, Oaxaca: Los primeros cien años de la colonia (1533-1617). Research School of Asian, African, and Amerindian Studies (CNWS), Universiteit Leiden, Leiden, Netherlands.

2004 La antigua sociedad indígena a través de sus propios documentos: Reconstrucción del patrón de asentamiento y de la tenencia de la tierra en el pueblo de San Miguel Tulancingo alrededor de 1600. In Estructuras políticas en el Oaxaca antiguo: Memoria de la tercera mesa redonda de Monte Albán, edited by Nelly M. Robles García, pp. 261-83. Instituto Nacional de Antropología e Historia, Mexico City.

2010 Asentamiento y transición en el Lienzo de San Jerónimo Otla, Coixtlahuaca. Relaciones 31:55-105.

van Doesburg, Sebastián, and Michael W. Swanton

2011 Mesoamerican Philology as an Interdisciplinary Study: The Chochon (Xru Ngiwa) "Barrios" of Tamazulapan (Oaxaca, Mexico). Ethnohistory 58: 613-652.

van Doesburg, Sebastián, and Olivier van Buren

1997 The Prehispanic History of the Valley of Coixtlahuaca, Oaxaca. Cuadernos de Historia Latinoamericana 5:103-160.

Widgren, Mats

2007 Precolonial Landesque Capital: A Global Perspective. In Rethinking Environmental History: WorldSystem History and Global Environmental Change, edited by Alf Hornborg, J. R. McNeill, and Joan Martinez-Alier, pp. 61-77. AltaMira Press, Lanham, Maryland.

Submitted July 12, 2016; Revised September 23, 2016; Accepted April 25, 2017 